\title{
JAPONIA
}

Irena Rychłowska

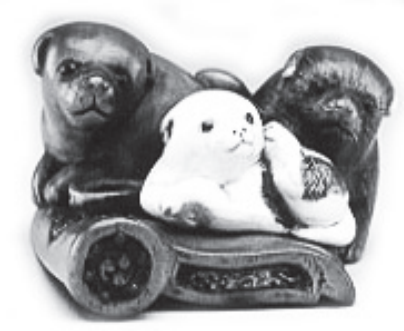

\section{ODPOCZYWAJĄCY MIŚ, CZYLI JAK JAPOŃCZYCY RADZA SOBIE ZE STRESEM I ZMĘCZENIEM. NOTATKI PODRÓŻNE'}

Dziś znowu nie zdarzyło się nic szczególnie dobrego. Ani nic szczególnie złego. Raz aż mnie w środku ścisnęło ze złości, ale to przecież normalne. Wstałam o szóstej, wyszłam do pracy, zjadłam lunch, miałam nadgodziny, wróciłam do domu, w którym nie czekało na mnie zapalone światto. Dzień taki sam jak wczoraj, taki sam jak rok temu. Ach! Jaki to dziś serial w telewizji? Nacisnętam chłodna klamkę. I wtedy, w mieszkaniu zobaczyłam... misia ${ }^{2}$.

Tak zaczyna się jeden z ilustrowanych tomików, które w Japonii stoją w księgarniach na półkach z napisami: „Relaks” lub „Dla kobiet”. Te same książeczki, wraz z towarzyszącymi im pluszowymi czy plastikowymi maskotkami i gadżetami - notesami, długopisami, kalendarzami, torebkami, poduszkami i czym tylko dusza zapragnie - kupić można w sklepach z zabawkami. Takimi, jak np. wielopiętrowy tokijski „Kiddy Land”, który reklamuje się hasłem: „For the human smile” - „dla ludzkiego uśmiechu”, wypisanym w języku angielskim, ale w zgodzie z logiką kultury japońskiej. Bo w kulturze, gdzie rzeczy mają duszę, służą one ludziom, choćby tylko wywołując uśmiech, ale najczęściej jako talizmany czy amulety ${ }^{3}$. W kulturze japońskiej bardzo ceni się dzieciństwo, a cechy kojarzone na Zacho-

${ }^{1}$ Krótsza wersja tekstu, pod tytułem: Japoński sposób na stres. Dzisiaj przewalamy się wszyscy z boku na bok, została opublikowana w „Rzeczypospolitej” z 11 maja 2007 r.

2 Aki Kondō, Rilakkuma seikatsu [Życie Relaksmisia], Shufu to Seikatsusha Ltd., Tokio 2004, s. 2. W tekście i przypisach stosuję wygodniejszą dla czytelnika polskiego konwencję zachodnią: najpierw imię, potem nazwisko.

3 Zarówno przedmioty wywołujące uśmiech, jak i talizmany/amulety kreują „,pomyślną konfigurację", zapewniają odpowiedni kontekst, zapobiegają negatywnym emocjom. Zob. (także w kwestii duszy przedmiotów) - Irena Rychłowska, Elementy psychogeografii Tokio: współczesna metropo- 
dzie z pogardzaną w naszym kręgu kulturowym „dziecinnością” (jak np. potrzeba zależności) nie są w Japonii postrzegane jako brak dojrzałości ${ }^{4}$. Toteż sklepy z zabawkami reklamują się - tak jak „Kiddy Land” - hasłami typu: „czyste dziecięce przyjemności dla wszystkich grup wiekowych!” lub: „dzięki nam zachowasz na zawsze młody umysł, ciało i duszę" producenci zabawek adresują swe produkty do dorosłych. Pluszowymi misiami fascynują się przede wszystkim dorośli - i kupują je dla siebie.

Trzy niewielkie książeczki o misiu imieniem „Rilakkuma” (czyli „Relaksmiś”) wraz z dwoma tomikami zawierającymi nalepki z tymże niedźwiadkiem osiagnęły łącznie, już po roku sprzedaży, a więc w 2005 r., ponad milion egzemplarzy ${ }^{6}$. Jak informowała, opierając się na danych z tegoż 2005 r., gazeta „Nihon Keizai Shimbun" (Nikkei), wprawdzie Rilakkuma ustępował w owym czasie popularnością kilku innym tego typu produktom, choćby Kubusiowi Puchatkowi, ale zarazem była to jedyna postać, na którą popyt stale róst7. Zaznaczono tam, że sprzedaż każdej z pozostałych zabawek maleje, ponieważ na rynku japońskim pojawia się tego typu postaci coraz więcej ${ }^{8}$ - jest zatem z czego wybierać. Miś jest nieustająco popularny już piąty rok, zaś liczba różnego rodzaju pozycji wydawniczych z nim związanych wzrosła do dziewiętnastu?. W tym roku sklepy z zabawkami i combini - niewielkie, sieciowe, wielobranżowe sklepy całodobowe (nazwa pochodzi od angielskiego convenient stores) - w ramach obchodów piątych urodzin niedźwiadka (maskotka ukazała się w sprzedaży nieco wcześniej niż wspomniane książki, które zapoczątkowały jego olbrzymią popularność) - oferują rozma-

lia i tradycje japońskie, w: Krzysztof Gawlikowski, Małgorzata Ławacz (red.), Japonia na poczatku XXI wieku. Polityka, gospodarka, społeczeństwo i stosunki z Polska, Wydawnictwo Adam Marszałek, Torun 2008.

${ }^{4}$ Por. np. Yamamura Yoshiaki, The child in Japanese society, w: Harold Stevenson, Hiroshi Azuma, Kenji Hakuta (eds.), The child development and education in Japan, W.H. Freeman and Co., New York 1986 oraz Takeo Doi, The anatomy of dependence, Kodansha International, Tokyo 2001.

${ }_{5}$ Por. hasło wydrukowane na koszulkach sprzedawanych w sklepie „Kiddy Land” kwiecień 2006, w oryginale: „Pure childish pleasures, all ages welcome”, oraz hasło na stronie internetowej sklepu: „Kiddy Land helps keep your mind, body and soul youthful, now and forever”, [@:] http:// www.kiddyland.co.jp/en/about.html.

${ }^{6}$ [Brak autora], Rilakkuma series sales top one million copies. Publisher throws a thank-you party for books' author, strona TranNet KK, Japanese Writers' House, [@:] http://www.trannet-japan. com/ep/tjc_news_dtl.asp?dk=N0000009.

${ }^{7}$ [Brak autora], Shōhi o tsukumu 3. Urite no shin hassō. Omake no 'shōhin ryoku'[Przyciagnąć konsumentów, odc. 3. Nowe idee sprzedawców. Siła bonusów], „Nikkei” 8 sierpnia 2006, s. 11.

8 Ibidem.

9 Dane z 20 września 2008 r. (łącznie z książkami kucharskimi i poradnikami rękodzieła). Listę książek można znaleźć (za pomocą funkcji: „wyszukiwanie”) na stronie wydawnictwa Shufu to Seikatsusha: [@;] http://www.shufu.co.jp (nazwa wydawnictwa to w thumaczeniu: „gospodyni domowa i życie"). 
ite wizerunki Rilakkumy w koronie i stroju królewskim. Po polsku można by to skomentować kolokwialnym wyrażeniem: „miś rządzi!”. Początkowo Relaksmisia kupowały przede wszystkim kobiety w wieku 20-30 lat, potem stał się popularny także wśród mężczyzn i we wszystkich grupach wiekowych ${ }^{10}$. Skąd wzięło się tak wielkie jego powodzenie?

Bohaterka opowieści o misiu to, pojawiająca się w niej epizodycznie, 25-letnia Kaoru - office lady $(O L)$, czyli osoba płci żeńskiej, wykonująca proste prace biurowe. W Japonii na stanowisku takim pracują kobiety przed zamążpójściem (od $O L$ oczekuje się, że odejdzie z pracy, wychodząc za mąż). W mieszkaniu Kaoru od dawna mieszka ,żółty ptak”, który wygląda jak skrzyżowanie kurczaka z kanarkiem. Ma do dyspozycji klatkę, do której czasem wchodzi, by zaraz z niej wyjść. Nie wiadomo, czy w ogóle umie latać. Tytułowy miś pojawia się w życiu młodej kobiety znienacka i ku jej zaskoczeniu. Zabiera jej ulubioną poduszkę i odpoczywa, pogryzając krakersy. Poza relaksowaniem się całymi dniami nie robi właściwie nic. Je (poznajemy jego ulubione dania). Przysypia. Słucha muzyki. Przewraca się z boku na bok. Wygrzewa w kąpieli. Śpi. Ogląda telewizję. Drzemie. Leży. Filozofuje. I oczywiście jest wyznawcą zasady: „Co masz zrobić dzisiaj, zrób jutro”.

Po jakimś czasie do mieszkania Kaoru wprowadza się jeszcze drugi miś: Korilakkuma („Mały Rilakkuma”). Status ontologiczny obu misiów nie jest rozstrzygnięty. Czym lub kim są? Rilakkuma ma na plecach suwak, spod rozpiętego suwaka widać materiał w błękitne groszki. Drugi miś ma na brzuchu guzik. Co jest pod spodem? Czy to pluszowe misie, czy ludzie lub inne istoty przebrane za misie? O takich produktach japońscy designerzy mówią: „plus alpha”. Takie przedmioty mają w sobie „to coś”, bo zawierają tajemnicę.

W książkach z serii: „Życie Relaksmisia” - na jednej stronie jest obrazek, a na drugiej krótki komentarz, np.: „Miś chrapie przykryty kocykiem. Kurczak zastanawia się: ,'off’ czy ‘on'? [włączony czy wyłączony?]"11. Miś klęczy nad zwiędniętym kwiatkiem w doniczce: „Widocznie takie było jego przeznaczenie...”. Kurczak komentuje: „Wodą byś go podlał" "2 Relaksmiś wpatrzony z uwagą w telewizor-ekran DVD. Na ekranie kąpielisko - gorące źródła, na podłodze okładka płyty z takim tytułem. Komentarz na drugiej stronie: „Czasem dobrze jest zapomnieć”. Obok małymi literkami: „Zapewnia to świeże doznania”"13. Miś suszy na sznurze swoje cztery pozostałe, brązowe futerka: „Codziennie takie samo, a jednak inne!”14.

${ }_{10}$ Tomomi Shibazaki, Goods Japan. Uwasa no guzzu 1 [Produkty, o których wiele się mówi] Rilakkuma, Psiko, 7 stycznia 2006.

${ }^{11}$ Aki Kondō, Kiiroi-tori. Rilakkuma seikatsu 3 [Żółty ptak. Życie Relaksmisia 3], Shufu to Seikatsusha Ltd., Tokio 2005, s. 72.

12 Aki Kondō, Rilakkuma seikatsu..., s. 90-91.

13 Ibidem, s. 96-97.

${ }^{14}$ Ibidem, s. 8-9. 
Rilakkuma jest nieruchawy i czasem trudno jest się mu podnieść. Jest nieco egoistyczny: na jego talerzu leży stos kilkunastu placków, na talerzu żółtego ptaka - jeden. Miś proponuje: „Nie kłóćmy się o drobiazgi”. Obok enigmatyczny napis: „Proszę. Częstuj się. Bierz, ile chcesz”15. Na innym obrazku: niedźwiadek nad trzema plackami zastanawia się: „Podzielić się, czy nie?”. Obok: „Szczęście to trochę co innego..." ${ }^{\prime 16}$.

Miś często leży zakopany w stosie papierków czy papierowych chusteczek. Nierzadko zabawia się, próbując wrzucać je z pewnej odległości do kosza (i nigdy nie trafia). Żółty ptak z kolei uwielbia sprzątać. Ale trzeba przyznać, że ma też inne hobby - czasem spomiędzy śmieci, z wypiekami na dziobku, udaje mu się wygrzebać pojedyncze monety, które skrzętnie chowa do słoika ${ }^{17}$. Doskonale się uzupełniają. Gdy miś, chrupiąc z zapałem twarde krakersy, stwierdza, zgodnie ze znaną japońską prawdą ludową: „Energiczne ruszanie szczęką dobrze robi na mózg”, ptak, znad zagranicznego elementarza dogaduje: „Zupełnie tak jak nauka?”"

„Dziś znów, i jutro też, przewalamy się wszyscy z boku na bok”, głosi bon-mot „Życia Relaksmisia”' ${ }^{\prime 9}$. Aki Kondō, autorka książek, przyznaje w jednym z wywiadów, że wymyśliła misia w czasie, gdy była bardzo zmęczona. Ale - dodaje - to nie jest jej ulubiony bohater. Jej ulubionym bohaterem od dziecka jest mały dinozaur Gachapin, pełen energii wielbiciel sportów ekstremalnych ${ }^{20}$. Nic dziwnego. Przecież w japońskim systemie wartości nadal, mimo rosnących wpływów Zachodu, nie ceni się czasu spędzonego bez celu, niewypełnionego czymś, co ma sens. Tu, gdzie pracuje się ciężko, a w każdym razie spędza w pracy wiele godzin, śpi w nocy krótko, zaś drzemie w pociagu w drodze do i z pracy, a na urlop (nawet, gdy leci się w tym celu na inny kontynent) wyjeżdża na kilka dni, w czasie wolnym odpoczywa się zazwyczaj z zapałem i zaangażowaniem. W każdym razie niewiele osób zdobywa się na przyznanie, że pewnego weekendu zdarzyło im się nie robić nic. Odpoczynek powinien być wypełniony jakaś dobrze zdefiniowaną aktywnością. Jak pisze w książce zatytułowanej What Is Japan? [Czym jest Japonia?] Taichi Sakaiya, Japończycy nawet bawiq się tak, jakby pracowa$l i^{2 l}$. Japoński etos pracy dobrze ilustruje, jego zdaniem, różnica między pierwotna, chińską postacią buddyzmu zen a jego późniejszą, typowo japońską postacią. We

\footnotetext{
${ }^{15}$ Ibidem, s. 30-31.

16 Ibidem, s. 98-99.

17 Por. np. Aki Kondō, Kiiroi-tori..., s. 18-19, 28-29 i nn.

18 Aki Kondō, Rilakkuma seikatsu..., s. 92-93.

19 W oryginale: „Kyō mo ashita mo minna de daradara goron”. Por. np: [@:] http://www.san-x. co.jp/relaxuma/top.html.

${ }^{20}$ [Brak autora], Aki Kondou, Maru-c lato 2005, s. 11.

${ }^{21}$ Taichi Sakaiya, What Is Japan? Contradictions and transformations, Kodansha International, Tokyo 1993, s. 226-227.
} 
wcześniejszej wersji dominujący obraz wygląda tak: założyciel zen, Bodhidharma, siedzi nieruchomo dziewięć lat twarzą do ściany, medytując. W późniejszej mnisi, gwoli oświecenia, całymi dniami pucują podłogi, nawet jeśli te są zawsze czyste $^{22}$. Japonia to kraj, w którym materialnych zasobów jest niewiele i którego możliwości ekspansji są ograniczone. Zaangażowanie w pracę, korzystne na poziomie przedsiębiorstwa, niszczy ekonomię w skali kraju. Zdaniem tego znanego ekonomisty, Japonia od przełomu XVII i XVIII w. pozostaje pod wpływem filozofii Shinroku Itō i Baigana Ishidy. Pierwszy zalecał angażować się z zapałem nie tylko w pracę, ale i w nieproduktywne aktywności ${ }^{23}$. Za sprawą drugiego pracę zaczęto postrzegać przede wszystkim jako środek do budowy charakteru (a jedynie wtórnie jako produktywną działalność $)^{24}$. Gdy Sakaiya w 1991 r. kończył przywoływaną tu książkę, Japonia była, jak twierdził, rajem producentów i piekłem konsumentów ${ }^{25}$. Dziś bez wątpienia jest to najbardziej rozwinięte społeczeństwo konsumpcyjne świata ${ }^{26}$.

Patrzę na „Zeszyt do zapisywania wydatków” dla gospodyń domowych, ozdobiony przewalającymi się z boku na bok misiami. Obserwuję Relaksmisia przyczepionego do telefonu nie tylko $O L$, ale i robiącej karierę bizneswoman, misia wiszącego przy zapięciu teczki urzędnika w czarnym garniturze. Przyglądam się zgarbionej w pałąk staruszce, pędzącej na swym rowerze w stronę dzielnicowego domu kultury i świątyni - ponieważ starsza pani bierze właśnie udział w organizacji święta. Do roweru przytroczyła laskę, z plecaka wystaje wielka rzodkiew, a do plecaka przyczepiony jest... odpoczywający miś. Może czasem ludzie ci marzą o tym, by nie robić nic. Ale, tak jak tybetański młynek modlitewny modli się zamiast wiernych ${ }^{27}$, miś odpoczywa za nich wszystkich, pozwalając im pracować zapamiętale.

${ }^{22}$ Ibidem, s. 225-226.

${ }^{23}$ Ibidem, s. 221-222. Shinroku Itō (1671-1733), lider bractwa czcicieli góry Fuji (Fujikō), znany jest bardziej jako Jikigyō Miroku; ową ,nieproduktywna aktywnością”, w ujęciu autora What is Japan, były przede wszystkim pielgrzymki na górę Fuji.

${ }^{24}$ Ibidem, s. 222-224. Baigan Ishida (1685-1744), uczony i edukator, założyciel ruchu „Shingaku" [Edukacja serca].

${ }^{25}$ Ibidem, s. 236.

26 John Clammer, Received dreams: Consumer capitalism, social process, and the management of the emotions in contemporary Japan, w: J.S. Eades, Tom Gill, Harumi Befu (eds.), Globalization and social change in Japan, Trans Pacific Press, Melbourne 2000, s. 211.

${ }^{27} \mathrm{~W}$ sprawie wagi i znaczenia, szczególnie współcześnie, kulturowych rozwiązań tego typu zob. Slavoj Žižek, The plague of fantasies, Verso, London 1997, s. 109-122, a zwłaszcza kategoria „,interpasywności” i ,przedmiotu, który doznaje rozkoszy/jest pasywny zamiast mnie, w moim imieniu" [lub polskie thumaczenie, oparte na zmienionej wersji książki: Slavoj Žižek, Przekleństwo fantazji, Wydawnictwo Uniwersytetu Wrocławskiego, Wrocław 2001, s. 169-184]. 